\title{
New morphospecies of Chamaesiphon (Cyanobacteria) from Atlantic rainforest, Brazil
}

\author{
Célia L. Sant ${ }^{\prime}$ Anna $^{1 *}$, Watson A. Gama-Jr. ${ }^{1}$, Maria Teresa P. Azevedo ${ }^{1} \&$ Jiří \\ KOMÁREK ${ }^{2}$ \\ ${ }^{1}$ Institute of Botany, Laboratory of Phycology, São Paulo, SP, Brazil; *corresponding author e-mail: celialsant@ \\ yahoo.com.br \\ ${ }^{2}$ Faculty of Science, University of South Bohemia, České Budějovice, Czech Republic
}

\begin{abstract}
The Atlantic rainforest is considered one of the most important hotspots of biodiversity on Earth. This great diversity results from the variation of climatic conditions (rainy, warm and cold in high mountains), what generates a unique series of rain forest ecosystems quite distinct from each other. Unfortunately, due to the human impact over the centuries, today there are just fragments of preserved native rainforest. During the investigation about the cyanobacterial flora from the Atlantic rainforest, a special Chamaesiphon morphotype was found on a rock in streaming water. Chamaesiphon stratosus sp. nova is close to C. britannicus (FriTsCH) КомÁReK et Anagn., C. geitleri Luther and C. fuscus (Rostaf.) Hansg., and differs from them mainly because of the cells disposition in one layer and exocytes liberation in a sheath at the upper part of cells. These two features belong to different subgenera of Chamaesiphon (Godlewskia and Chamaesiphonopsis). Thus, the Brazilian material displays features of both subgenera and puts in evidence the fragility of these characteristics at subgenus level. Therefore, a discussion about the taxonomy of these subgenera and a proposal for including Chamaesiphonopsis as a synonym of the Godlewskia were done.
\end{abstract}

Key words: Brazil, Atlantic rainforest, Chamaesiphon, new morphoespecies, epilithic habitat

\section{Introduction}

The Atlantic rainforest is one of the most important hotspots of biodiversity on Earth (MYERS et al. 2000). This ecosystem is disposed along the Brazilian Atlantic coast from the south to the northeast of the country (RIzZINI 1997), with a great diversity of habitats. Due to the variability of climatic conditions (rainy, warm and cold in high mountains), a series of rain forest ecosystems quite distinct from each other are formed (MitTERMEIER et al. 1999).

The Atlantic rainforest encompasses areas in Brazilian tropical and subtropical regions and in spite of its high diversity of habitats and richness of species, most of its biodiversity related to microorganisms, including that of Cyanobacteria (KomÁreK 2007; Fiore et al. 2007), is totally unknown. Besides that, the intense deforestation of the Atlantic rainforest has reduced the ecosystem to only $7 \%$ of its original coverage (MINISTÉRIO Do Meio Ambiente 2007).

During the investigation about the cyanobacterial flora in the Atlantic rainforest, a special Chamaesiphon morphotype growing on a rock in streaming water was found. The genus Chamaesiphon presents heteropolar cells and a special kind of reproduction characterized by asymmetrical binary fission and exocytes liberation. Most Chamaesiphon species has been registered to freshwater with epiphytic habit. KomÁreK \& ANAGNostidis (1998) listed 13 species exclusively epiphytic and submersed, 9 epilithic, and one with subaerophytic habitat. GolD-MORGAN et al. (1996) found in Central Mexico six taxa (five species and one variety) of Chamaesiphon and among them, five are epiphytic and one was growing on artificial substrate in a fountain. Recently, Chamaesiphon komárekii Rott, a new epilithic species from a Canadian forest stream (RоTт 2008) was described.

The genus Chamaesiphon is very little known in Brazil where there are only few references to its occurrence. UHERKOVICH \& FRANKEN (1980) cited Chamaesiphon sp. for the Amazonian region, FranceschinI (1983) 
mentioned the epiphytic $C$. confervicola A.Braun in RABENH. for the State of Rio Grande do Sul, and Bicudo (1988) and AzEvedo et al. (1996) referred C. investiens SKuJa in periphyton of a lake in São Paulo State. Necchi-JÚNIOR \& SANT'ANNA (1986) is the most complete work developed in Brazil about Chamaesiphon species, presenting description and illustrations of three species (C. confervicola, C. curvatus Nordst. and C. incrustans Grunow in Rabenh.) which are all epiphytes: the first and second on Batrachospermum (Rhodophyceae) and the third on Scytonema (Cyanobacteria), occurring in streams from São Paulo State. Recently, Chamaesiphon species in Brazil are mentioned only in lists of species occurring as epiphytes in streams and rivers (FONSECA \& RODRIGUes 2007; NECCHI-JÚNIOR et al. 2008).

The aim of this work is to characterize a new morphospecies of Chamaesiphon from a rock substrate in the Atlantic rainforest.

\section{Material and Methods}

The State Park of Campos do Jordão (22 41 '25"S; $45^{\circ} 28^{\prime} 5^{\prime}$ 'W) is located in São Paulo State, southeastern Brazil. The region is characterized by the presence of Araucaria forest located around $2000 \mathrm{~m}$ high with temperature average $14{ }^{\circ} \mathrm{C}$ (minimal down of $0{ }^{\circ} \mathrm{C}$ and maximal $30^{\circ} \mathrm{C}$ ) (MODENESI 1984).

The material was found on rock coverage by a running water film from a stream in the forest. The samples were gathered with a spatula and fixed in $4 \%$ formaldehyde solution. The material was studied under the light microscope to detail the morphological and metrical features of the population $(n=30)$.

\section{Results}

\section{Chamaesiphon stratosus sp. nov. (Figs 1-2)}

Diagnosis: Thallus epiliticus, stratosus, insidens in saxis in rivulis fluentibus, macula fusca, olivaceae vel ochracea formans ad expansus. Coloniae condensatae, fruticulosae, flabelliformes. Cellulae paralleliter perpendiculariterque, dense dispositae, basim ad substratum affixae, plus minusve irregulariter claviformes, basim et ad apices rotundatae, praecipue in strato uno dispositae, 9.3-26.8 $\mu$ m longae, 2.3-6.5 um latae. Cellulae contentu fusco vel olivaceo, paucim granulatae. Pseudovagina U-formata, distincta, firma, sine colore vel ad intense luteo-viridis vel brunescens, paucim lamellata, vetusta, infundibuliformis, apice late aperta, basim clausa. Exocyta 1.5-2.6 $\mu \mathrm{m}$ diametro, plerumque in parte superior pseudovaginae in massis agglomerata, rare stratum secundum superior formans, vel singulares liberantur.

Habitatio: In saxis in rivulis cum aqua rapide fluitans; locus classicus: Brasilia, provincia Sao Paulo, in comitatu Campos de Jordão (2241'26.3'"S; 4528'51.4"W).

Typus (holotypus): Exsiccatum SP400963; dep. in herbarium (SP) Institute of Botany, SP, Brazil; icona typica figurae nostrae 1.

Thallus forming brown to olive-green spots on rock and stones. Colonies compact, shrub-like, fan-shaped, composed of parallel arranged cells oriented perpendicularly to the substrate. Cell more or less irregular club-shaped, rounded at both ends, organized in one layer or at most two, 9.3-20.6(26.8) × 2.3-4(6.5) $\mu \mathrm{m}$. Cells content brownish or olive-green, slightly granular. Sheath U-shaped, distinct, firm, colorless to intensely yellowish-green or brownish, slightly lamellate and frayed when old, widely opening at apical end and closed at the basis. Exocytes 1.5-2.6 $\mu \mathrm{m}$ diameter, generally forming mass with variable number of rows and layers on the upper part of the mother cells where they rarely germinate. They can be also singly liberated from the mother cells.

Habitat: On rock coverage by rapid running water from a stream in the forest.

Type locality: Brazil, in State Park, municipality of Campos do Jordão, São Paulo State, Brazil (2241'26.3”'S; 45²8'51.4”'W).

Table 1. Comparison between the three sub-genera of Chamaesiphon (KoMÁReK \& ANAGNOSTIDIs 1998).

\begin{tabular}{llll}
\hline Chamaesiphon sub-genera & Chamaesiphon & Chamaesiphonopsis & Godlewskia \\
\hline Cells arrangement & $\begin{array}{l}\text { solitary, not forming layered } \\
\text { colonies }\end{array}$ & $\begin{array}{l} \pm \text { densely and parallely } \\
\text { oriented in one layer } \\
\text { colonies }\end{array}$ & $\begin{array}{l}\text { forming shrub-like } \\
\text { groupings or large layered } \\
\text { colonies }\end{array}$ \\
$\begin{array}{ll}\text { Exocytes disposition and } \\
\text { liberation }\end{array}$ & $\begin{array}{l}\text { liberated after formation, not } \\
\text { ramaining in the colonial } \\
\text { mucilage }\end{array}$ & $\begin{array}{l}\text { soon separeted or remain for } \\
\text { a short time at the margin of } \\
\text { sheaths }\end{array}$ & $\begin{array}{l}\text { attached to the margin of } \\
\text { sheaths or remain in colonial } \\
\text { mucilage }\end{array}$ \\
\hline
\end{tabular}


Table 2. Comparison between Brazilian material and its closest Chamaesiphon species.

\begin{tabular}{|c|c|c|c|c|}
\hline & Subg. Chamaesiphonopsis & Subg. Godlewskia & & \\
\hline & C. britannicus & C. fuscus & C. geitleri & C. stratosus \\
\hline Colour of mass & brown spots & $\begin{array}{l}\text { dark rusty brown to blackish } \\
\text { (several } \mathrm{cm}^{2} \text { ) }\end{array}$ & $\begin{array}{l}\text { dark brown to blackish, } \\
\text { irregular spots }\end{array}$ & $\begin{array}{l}\text { olive-green (up to several } \\
\mathrm{cm}^{2} \text { ) }\end{array}$ \\
\hline Cells diposition & $\begin{array}{l}\text { densely and paralelly } \\
\text { packed in 1-3(4) layers }\end{array}$ & $\begin{array}{l}\text { densely and parallely } \\
\text { arranged in 1-2(3) layers - } \\
\text { Dinobryon-like }\end{array}$ & $\begin{array}{l}\text { densely and parallely arranged } \\
\text { in 2(5) layers - shrub-like }\end{array}$ & $\begin{array}{l}\text { compact and parallely } \\
\text { arragend in } I(2) \text { layer - fan- } \\
\text { shaped }\end{array}$ \\
\hline Cell lenght $(\mu \mathrm{m})$ & $10.5-14$ & $5-13(22)$ & $(4) 5-20(30)$ & $9.3-20.6(26.8)$ \\
\hline Cell diameter $(\mu \mathrm{m})$ & $3.5-4.5(5)$ & $(2.5) 3-7$ & $2.5-6.5(9.6)$ & $2.3-4(6.5)$ \\
\hline Sheaths & fine, diffluent & $\begin{array}{l}\text { thin to slightly thickened, } \pm \\
\text { V-shaped }\end{array}$ & $\begin{array}{l}\text { thick, lamellate, V-or-funnel- } \\
\text { shaped }\end{array}$ & $\begin{array}{l}\text { firm, thick, lamellate, U- } \\
\text { shaped }\end{array}$ \\
\hline \multicolumn{5}{|l|}{ Cell shape } \\
\hline Exocytes liberation & $1-2$ & $1-2$ & $1-2$ or in a short simple row & $\begin{array}{l}\text { Forming mass in the upper } \\
\text { part of colony or singly }\end{array}$ \\
\hline Habitat & $\begin{array}{l}\text { Epiphytic in clear stagnant } \\
\text { waters (splash zone) }\end{array}$ & $\begin{array}{l}\text { Epilithic (non-calcareous } \\
\text { stony) in running waters }\end{array}$ & $\begin{array}{l}\text { Epilithic in streams and } \\
\text { waterfalls (always submersed) }\end{array}$ & $\begin{array}{l}\text { Epilithic on rock under a } \\
\text { water film }\end{array}$ \\
\hline Ocurrence & Temperate zone & Temperate zone & Temperate zone & Tropical zone \\
\hline
\end{tabular}

The main diacritical features to distinguish Chamaesiphon stratosus from its closest species (Table 2) is the parallel cells disposition mainly in one layer, exocytes formation generally in mass and by its occurrence in tropical zone. The frequent formation of a mass of exocytes instead of their liberation one by one might represent a protection mechanism against water flow impact. This characteristic is not normally found in the other Chamaesiphon species. Another population of Chamaesiphon stratosus growing also on rock in stream was found in different area of Atlantic rainforest located in a State Park, Municipality of Itupeva, São Paulo State $\left(23^{\circ} 08^{\prime} 54^{\prime \prime} \mathrm{S}\right.$ and $47^{\circ}$ $033^{\prime} 8^{\prime \prime} \mathrm{W}$ ).

\section{Discussion}

JANCZEWSKI (1883) described the genus Godlewskia as epiphyte on Batrachospermum, with bottle shaped cells and rounded exocytes disposed in series on the upper part of the vegetative cells. These exocytes develop attached to the mother cell giving a disorganized aspect to the old colonies. FritsCH (1929) proposed the genus Chamaesiphonopsis based on material described as "parenchymatous basal layer composed of closely fitting polygonal cells with firm but thin membranes, which form a prominent
network".Accordingtothisauthor, the differencebetween Chamaesiphon and Chamaesiphonopsis is the germination of exocytes in situ and a large number of exocyte producing cells united to form a compact basal stratum in Chamaesiphonopsis. Other characteristic described to this genus is the tendency to develop upright rows. Geitler (1932) included Chamaesiphonopsis, Godlewskia and some other genera (Sphaerogonium RostAF., Brachythrix A. Braun in Rabenh. and Hyellococcus SCHMidLE) as synonymous of Chamaesiphon, and divided this genus into three sections: Brachythrix, Euchamaesiphon and Godlewskia. The sections were separated considering the organization of tallus and features of exocyte (amount and liberation process).

Based on the proposal of GeitLER (1932), KomÁreK \& ANAGNostidis (1995) changed the section Godlewskia to a subgenus status and created the subgenus Chamaesiphonopsis based on the genus described by FRITSCH (1929). Later, KOMÁREK \& ANAGNOSTIDIS (1998) divided the genus Chamaesiphon into three sub-genera differentiated by disposition and arrangement of the cells and by formation and liberation of exocytes: Chamaesiphon (based on Geitler's concept of Euchamaesiphon and Brachythrix), Chamaesiphonopsis and Godlewskia (Table 1). However, the distinction between the two last subgenera is not clear once there are species with 

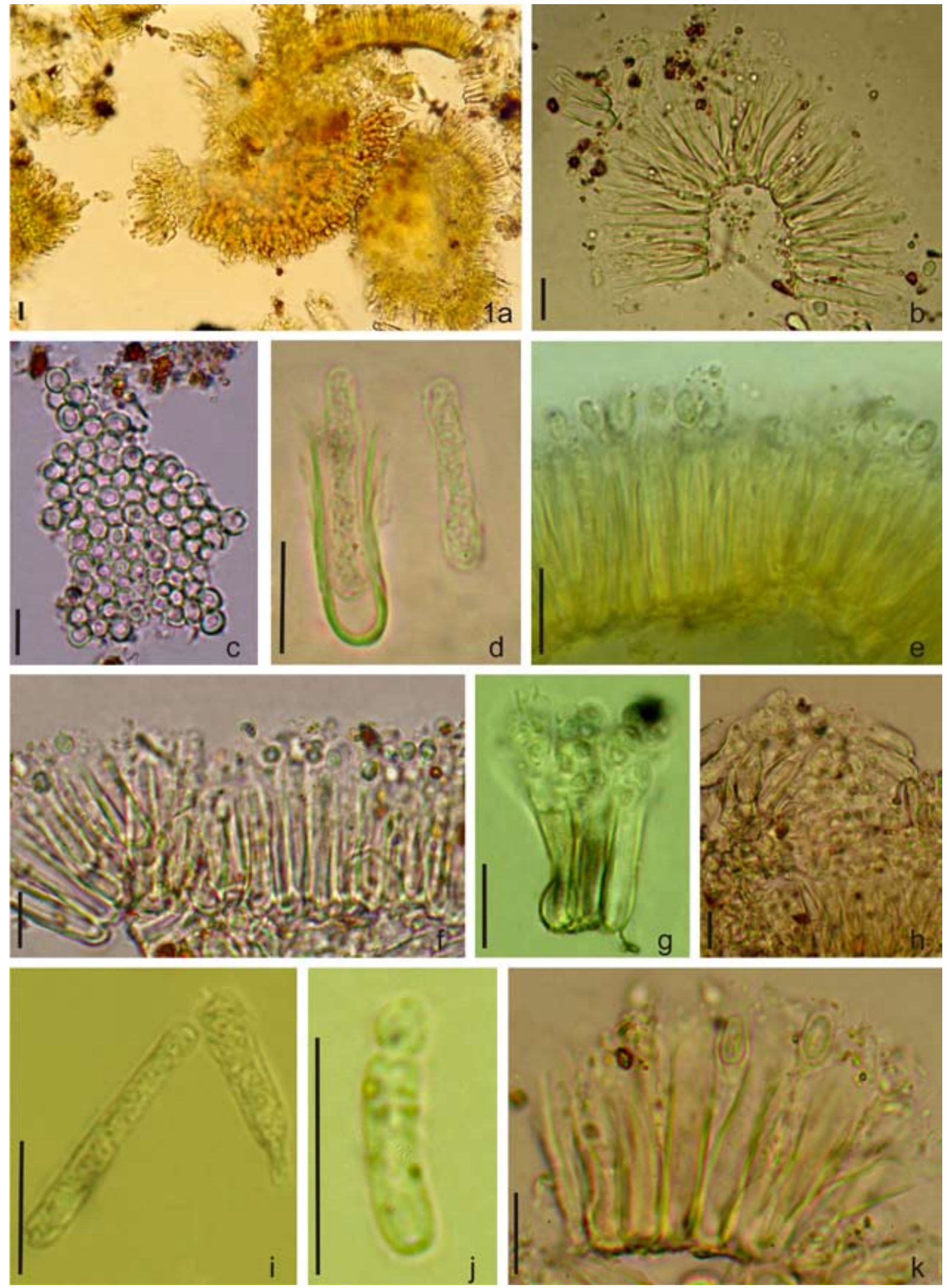

Fig. 1. Chamaesiphon stratosus: (a) general aspect of colonies; (b) fan-like colony; (c) apical view of colony; (d) cell showing lamellate sheath; (e) colony with parallel cells disposition; (f) exocytes liberation; $(\mathrm{g}-\mathrm{h})$ exocytes forming rows and layers after the liberation from the mother cells; (i) old cells showing club-shaped form; (j) exocyte formation; (k) initial stage of cell development forming the second layer. Scale bar $10 \mu \mathrm{m}$. 

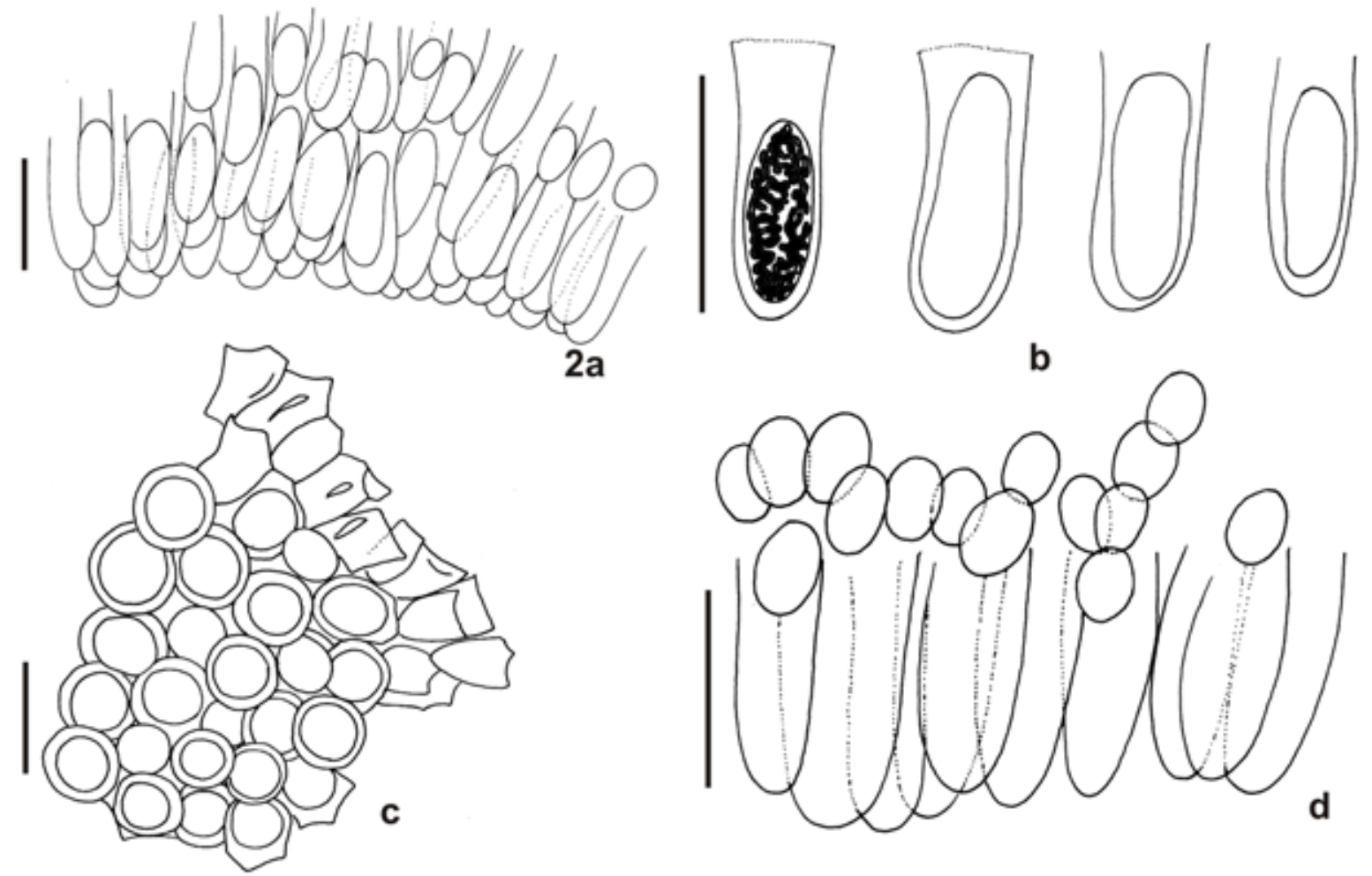

b

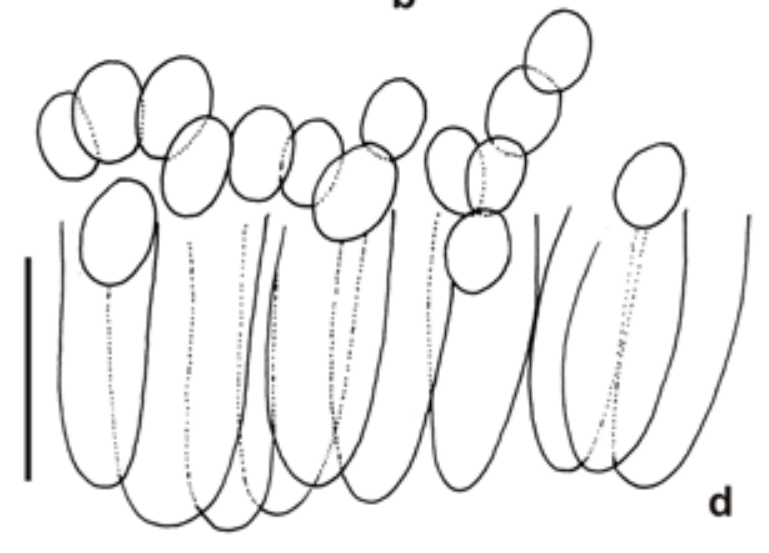

Fig. 2. Chamaesiphon stratosus: (a) general aspect of colonies; (b) different kind of cells shape and cell content with granules; (c) apical view of colony; (d) formation and liberation of exocytes. Scale bar $10 \mu \mathrm{m}$.

characteristics of both. Chamaesiphon britannicus (Fritsch) KomÁreK et Anagn. is the only species of the subgenus Chamaesiphonopsis and has the cells organized in one or three layers, rarely four, and so, it is in disagreement with the description of subgenus Chamaesiphonopsis (cells disposed in one layer, as described by KOMÁREK \& ANAGNOSTIDIS 1998). Thereby, the cells disposition is not a consistent feature in the differentiation of subgenera Chamaesiphonopsis and Godlewskia (layered colonies). Besides, both subgenera can display exocytes attached to the mother cells after liberation.

Considering that the distinction between Chamaesiphonopsis and Godlewskia is not reliable, we propose to consider the first as synonym of the second (concept of priority according to the Code of Botanic Nomenclature). Thus, the genus Chamaesiphon should be composed of two subgenera: Chamaesiphon (unicellular tallus) and Godlewskia (colonial tallus formed by cells disposed in one or more layers). The species Chamaesiphon britannicus should be transferred to the subgenus Godlewskia. Chamaesiphon komárekii has to be also included in Godlewskia because the material forms colonies, and not in the subgenus Chamaesiphon as proposed originally (Rотт 2008). The Brazilian morphotype has one-layer colonies as it is typical of Chaemaesiphonopsis and exocytes attached in the mucilage on the upper part of the cells as in the subgenus Godlewskia. Thus, the Brazilian new morphotype displays characteristics of both subgenera, further strengthening the fragility of the features used for distinguishing these subgenera and should be placed also in the subgenus Godlewskia.

\section{Acknowledgements}

We thank the financial support of $\mathrm{CNPq}$ (Process number 308086/2004-0) and CAPES for the fellowship to the second author.

\section{References}

Azevedo, M.T.P., Nogueira, N.C. \& Sant'anna, C.L. (1996): Criptógamos do Parque Estadual das Fontes do Ipiranga, São Paulo, SP. Algas 8: Cyanophyceae. - Hoehnea 23: 1-38.

Bicudo, D.C. (1988): Algas epífitas do Lago das Ninféas, São Paulo, Brasil, 1: Cyanophyceae. Rev. Bras. Biol. 48: 407-419.

Fiore, M.F, Sant'anna, C.L., Azevedo, M.T.P., 
KomÁreK，J., Kaštovský, J., Sulek, J. \& Lorenzi, A. (2007): The cyanobacterial genus Brasilonema - molecular and phenotype evaluation. - J. Phycol. 43: 789-798.

FonsecA, I.A. \& Rodrigues, L. (2007): Periphytic Cyanobacteria in different environments from the upper Paraná river floodplain, Brazil. - Acta Limnol. Bras. 19: 53-65.

FrANCESCHINI, I.M. (1983): Levantamento das Nostocophyceae do Rio Seco, Torres, Rio Grande do Sul, Brasil. - 157 pp., Universidade Federal do Rio Grande do Sul, Porto Alegre.

FRITSCH, F.E. (1929): The encrusting algal communities of certain fast-flowing streams. - The New Phytologist 28: 165-197.

Geitler, L. (1932): Cyanophyceae. - In: Rabenhorst's Kryptogamenflora, 14. - 1196 pp., Akad. Verlagsges., Leipzig.

Gold-Morgan, M., Montejano, G. \& Komárek, J. (1996): Freshwater epiphytic Chamaesiphonaceae from Central Mexico. Algological Studies 83: 257-271.

JANCZEWski, M.E. (1883): Godlewskia - Nouveau genre d'algues de l'ordre des Cryptophycées (1). - Ann. Sci. Nat., Bot. 16: 227-230.

KomÁreK, J. \& Anagnostidis, K. (1998): Cyanoprokaryota. 1. Teil Chroococcales. - In: Ettl, H.,GÄrtner, G.,Heynig, H. \& Mollenhauer, D. (eds): Süßwasserflora von Mitteleuropa 19/1. - 548 pp., Gustav Fischer Verlag, Stuttgart - Jena.

KomÁreK, J. \& ANAGNOSTIDIS, K. (1995): Nomenclatural novelties in chroococcalean cyanoprokatyotes. - Preslia 67: 15-23.

KomÁreK, J. (2007): Taxonomic evaluation of the cyanobacterial microflora from alkaline marshes of northern Belize. 1. Phenotipic diversity of coccoid morphotypes. - Nova Hedwigia 84: 65-111.

Ministério Do Meio Ambiente (2007): Áreas Prioritárias para a conservação, uso sustentável e repartição dos benefícios da biodiversidade brasileira. - 300 pp., Centro de Informação, Documentação Ambiental e Editoração Luís Eduardo Magalhães, Brasília.

Mittermeier, R.A., Myers, N., Robles-Gil, P. \& Mittermeier, C.G. (1999): Hotspots. Earth's Biologically Richest and Most Endangered Terrestrial Ecoregions. - 432 pp. CEMEX/ Agrupación Sierra Madre, Ciudad de México.

Modenesi, M.C. (1984): Evolução quaternária de uma montanha tropical: o planalto de Campos do Jordão São Paulo. - Ver. IG 5: 7-13.

Myers, N., Mittermier, R.A., Mittermier, C.G., FonseCA, G.A.B. \& Kent, J. (2000): Biodiversity hotspot for conservation priorities. - Nature 403: 845-853.

NeCChI-JÚnior, O., Branco, L.H.Z.\& SpeZAmiglio, D.N.
(2008): Distribuição ecológica de comunidades de macroalgas de ambientes lóticos do Parque Nacional de Itatiaia (RJ, MG), Brasil. - Rev. Bras. Bot., 31: 135-145.

NecChI-JÚnior, O. \& SAnT'AnNA, C.L. (1986): Taxonomic studies of some Chamaesiphonales (Cyanophyceae) from the State of São Paulo, southeastern Brazil. - Rev. Bras. Bot., 9: 201206.

Rizzini, C.T. (1997): Tratado de fitogeografia do Brasil. - 747 pp., $2^{\mathrm{a}}$ Ed., Âmbito Cultural Edições Ltda, Rio de Janeiro.

Rotт, E. (2008): Chamaesiphon komárekii species nova, a new benthic freshwater chroococcalean species (Cyanophyta/ Cyanobacteria) from western coniferous forest streams in British Columbia, Canada. - Algological Studies 126:37-46.

Uherkovich, G. \& Franken, M. (1980): Aufwuchsalgen aus Zentralamazonischen Regenwaldbächen. Amazoniana 7: 49-79.

(C) Czech Phycological Society (2011)

Recieved Sept 2010

Accepted Dec 2010 